\title{
Work Performance of MB Trac 900 Tractor on Mountains Terrain in Turkey
}

\author{
Tolga Ozturk and Murat Demir \\ University of Istanbul, Faculty of Forestry, Department of Forest Construction and \\ Transportation 34473 Bahcekoy,Sariyer, Istanbul, Turkey
}

\begin{abstract}
The forestry works mainly involves such various stages as growing, protection, production, wood harvesting, marketing and utilization of forest products. Wood harvesting is performed by completion of cutting, extraction and transporting stages. The most obvious feature of wood harvesting is that the operations are done under various weather conditions open in the field. The measurements and observations were made on 25 work made under different working conditions during cable pulling with MB Trac 900 forest tractor at the harvesting area. The time determinations were made with continuous time measuring technique. Regression analyses were employed for determining the factors. In this study, the results of studies carried out on the MB Trac 900 forest tractor operated in the Artvin region located in the Northeast Turkey are presented.
\end{abstract}

Key words: Turkey, MB Trac 900, Extraction, Forest Tractors, Wood Harvesting

\section{INTRODUCTION}

The transport of forestry products is realized in two stages. The first one is the primary transport stage which involves the haulage of timbers, while the second one is the secondary transport stage involving the main stage of transport of timbers, generally realized by trucks on forest roads [1].

However, the increasing of forest product that is formed in our country recently, now hauling has been still made with old patterns, such as sliding, throwing, circling, transport with human, skidding with animals on direct ground. Besides special forest tractors and skylines are used in some areas. The level of harvesting mechanization in developed countries is higher than Turkey. While mechanical harvesting is about $86 \%$ in Austria that is similar to Turkey, this ratio is about $9 \%$ in Turkey [2].

In this study, Taşlica Forest District is determined as research area. This district depend on Artvin Forestry Operation in Artvin Region Forestry Directorate and have one productivite area.

\section{MATERIALS AND METHODS}

In the district where this study was carried out, the location named Gitancuvar Hill represents the minimum elevation with $1186 \mathrm{~m}$ above. Sea level while Kizılkaya Hill the maximum elevation with $1483 \mathrm{~m}$ above sea level. The minimum slope was measured to be $10 \%$ while the maximum slope to be $80 \%$. The road density in the area is $14 \mathrm{~m} / \mathrm{ha}$.

The studied area for the productivity of a MB Trac 900 was in Taslica of Artvin. This one area belong to the
Artvin province located in Northeast Turkey as shown in Fig. 1. The total area of Artvin province is 712882 ha and $55 \%$ of this area is covered with forests [3]. The major trees species are Picea orientalis, Abies bornmülleriana, Pinus sylvestris and Fagus orientalis in forests of Artvin.

MB Trac 900 Mercedes tractor with an engine power of 85 HP were used in this study. Technical features of this tractor are shown in Table 1.

Daily transport capacity of tractor is $40-60 \mathrm{~m}^{3}$ on the average. Drawing rope is $12 \mathrm{~mm}$ in thickness and has a length of $100 \mathrm{~m}$. Two workers are employed in operating the tractor [4].

Before all else, making the varians analysis in the time measures, measure numbers that are in the level of confidence $95 \%$ are designated enough or not. Than again, the simple and plural regreation equations are appeared in the same level of confidence.These are determined the way of maximum correlation coefficient and the minimum error percentage. Findings values are tested with the value of $t$ and the test of $F$. One of the part of these statistics studies and graphics are made with SPSS 10.0 statistics programme.

In productive area with the studies of MB Trac 900 is made time measure in order to be appeared the production of machine and to find which factors are effective on these productions. Time measures are made in the productive time of the very dense period of the tractor.

Time measures are made according to the work stages that were determined before with the repetition, the technique of time measure and digital chronometer. Study report card are filled with finding the definite period of time of each work stage. The daily study hour 
of machine is 8 hours $[1,4,5,6,7]$. In order to be made the time studies, tractor's a piece of work for one time are determined in the followings $[1,2,4,5,6,8]$;

* Time required for the tractor to be brought to the place of loading. (S)

* Time required for the loading to be tied to the loading hook (1. Cable) (S-CP)

* Time required for the loading to be tied to the loading hook (2. Cable) (S-CP)

* Time required for drawing the loaded hook (1. Cable) (S-CP)

* Time required for drawing the loaded hook (2. Cable) (S-CP)

* Time required for the tractor to be brought down to the place of unloading. (S)

* Time required for untying the load from the hook. (S-CP)

* Total time required. (S-CP)

(S: Skidding to $300-600 \mathrm{~m}$; CP: Cable Pulling to $30 \mathrm{~m}$ )

\section{RESULTS AND DISCUSSION}

The Taşlica District operating under the management of Artvin Forestry Operations office was chosen as the study area for timber haulage operations. All workers employed at tractor operations were housed in the
Table 1: Technical Features of MB Trac 900 Tractor

\begin{tabular}{ll}
\hline Features & MB Trac 900 \\
\hline Machine Power & $85 \mathrm{HP}(63 \mathrm{kw})$ \\
Weight & $6000 \mathrm{~kg}$ \\
Drawing Power & 2 X 6083 daN \\
Speed & $30 / 40 \mathrm{~km} / \mathrm{hour}$ \\
Cylinder & 4 cylinder \\
Cylinder Capacity & $3780 \mathrm{~cm}^{3}$ \\
Cooling System & Water Cooling \\
Speed - front & $25-40 \mathrm{~km} / \mathrm{hour}$ \\
- back & \multicolumn{1}{c}{$20 \mathrm{~km} / \mathrm{hour}$} \\
Vinch Mark & CG2M2ZD \\
Cable Diameter & $12 \mathrm{~mm}$ \\
Cable Length & $100 \mathrm{~m}$ \\
Cable Speed - 540 tour & $33 / 61 \mathrm{~m} / \mathrm{min}$ \\
& $19 / 35 \mathrm{~m} / \mathrm{min}$ \\
Lift up Power & $2000 \mathrm{daN}$ \\
Depot Capacity & $120 \mathrm{lt}$ \\
Machine Type & OM 314 \\
Output & $3.30-8.40 \mathrm{~m} / \mathrm{hour}$ \\
\hline
\end{tabular}

barracks located within the forest area.

In that district, production operations were carried using tractors for a total of 3 months, namely July, August and September during a year, hauling a total of $652 \mathrm{~m}^{3}$ timber. The $90 \%$ of total production realized in the district was transported by the forestry tractors.

Table 2: Average Time Investigation of MB Trac 900 Tractor

\begin{tabular}{|c|c|c|c|c|c|c|c|c|c|}
\hline $\begin{array}{l}\text { Run } \\
\text { Number }\end{array}$ & $\begin{array}{l}\text { The } \\
\text { tractor to } \\
\text { be } \\
\text { brought to } \\
\text { the place } \\
\text { of loading } \\
\text { (min) } \\
\text { a }\end{array}$ & $\begin{array}{c}\text { The loading to } \\
\text { be tied to the } \\
\text { loading hook } \\
\text { (1. Cable) } \\
\text { (min) } \\
\text { b }\end{array}$ & $\begin{array}{l}\text { The } \\
\text { loading to } \\
\text { be tied to } \\
\text { the loading } \\
\text { hook }(2 . \\
\text { Cable) } \\
\text { (min) } \\
\text { c }\end{array}$ & $\begin{array}{l}\text { Drawing } \\
\text { The } \\
\text { loaded } \\
\text { hook } \\
\text { (1.Cable) } \\
\text { (min) } \\
\text { d }\end{array}$ & $\begin{array}{l}\text { Drawing } \\
\text { The } \\
\text { loaded } \\
\text { hook } \\
\text { (2.Cable) } \\
\text { (min) } \\
\text { e }\end{array}$ & $\begin{array}{l}\text { The tractor } \\
\text { to be } \\
\text { brought } \\
\text { down to the } \\
\text { place of } \\
\text { unloading } \\
\text { (min) } \\
\text { f }\end{array}$ & $\begin{array}{l}\text { Untying } \\
\text { the load } \\
\text { from the } \\
\text { hook }\end{array}$ & $\begin{array}{c}\text { Total } \\
\text { time } \\
\text { required } \\
\\
\left(\begin{array}{c}\text { min }) \\
\mathrm{h}\end{array}\right. \\
\end{array}$ & $\begin{array}{c}\text { Amount, } \\
\text { Distance } \\
\text { of load }\end{array}$ \\
\hline $\begin{array}{l}\text { Average } \\
600 \mathrm{~m} \\
\text { Skidding } \\
\text { Average }\end{array}$ & 9.0 & 3.0 & 2.0 & 3.0 & 4.0 & 10.0 & 2.0 & 33.0 & $\begin{array}{l}3.498 \mathrm{~m}^{3} \\
600 \mathrm{~m}\end{array}$ \\
\hline $\begin{array}{l}300 \mathrm{~m} \\
\text { Skidding } \\
\text { Average }\end{array}$ & 4.0 & 3.0 & 3.0 & 3.0 & 2.0 & 4.0 & 2.0 & 21.0 & $\begin{array}{l}3.315 \mathrm{~m}^{3} \\
300 \mathrm{~m}\end{array}$ \\
\hline $\begin{array}{l}30 \mathrm{~m} \\
\text { Pulling }\end{array}$ & -- & 3.05 & 2.14 & 3.05 & 3.25 & -- & 2.03 & 13.52 & $\begin{array}{l}3.256 \mathrm{~m}^{3} \\
30 \mathrm{~m}\end{array}$ \\
\hline
\end{tabular}

Table 3: Data of the MB Trac 900 Tractor

\begin{tabular}{lcccccc}
\hline Tractors & $\begin{array}{c}\text { Hours } \\
\text { Productivite } \\
\left(\mathrm{m}^{3} / \mathrm{h}\right)\end{array}$ & $\begin{array}{c}\text { Daily } \\
\text { Productivite } \\
\left(\mathrm{m}^{3} / \text { day }\right)\end{array}$ & $\begin{array}{c}\text { Fuel } \\
(\mathrm{lt} / \mathrm{h})\end{array}$ & $\begin{array}{c}\text { Logging } \\
\text { Distance } \\
(\mathrm{m})\end{array}$ & $\begin{array}{c}\text { Average Slope } \\
(\%)\end{array}$ & $\begin{array}{c}\text { Average Cost } \\
\left(\$ / \mathrm{m}^{3}\right)\end{array}$ \\
\hline MB 900 & 6.360 & 50.880 & 4.17 & 600 & 15 & 9,80 \\
MB 900 & 9,471 & 75,768 & 3,5 & 300 & 13 & 7,31 \\
MB 900 & 13,954 & 111,634 & 3,0 & 30 & 40 & 4,65 \\
\hline
\end{tabular}




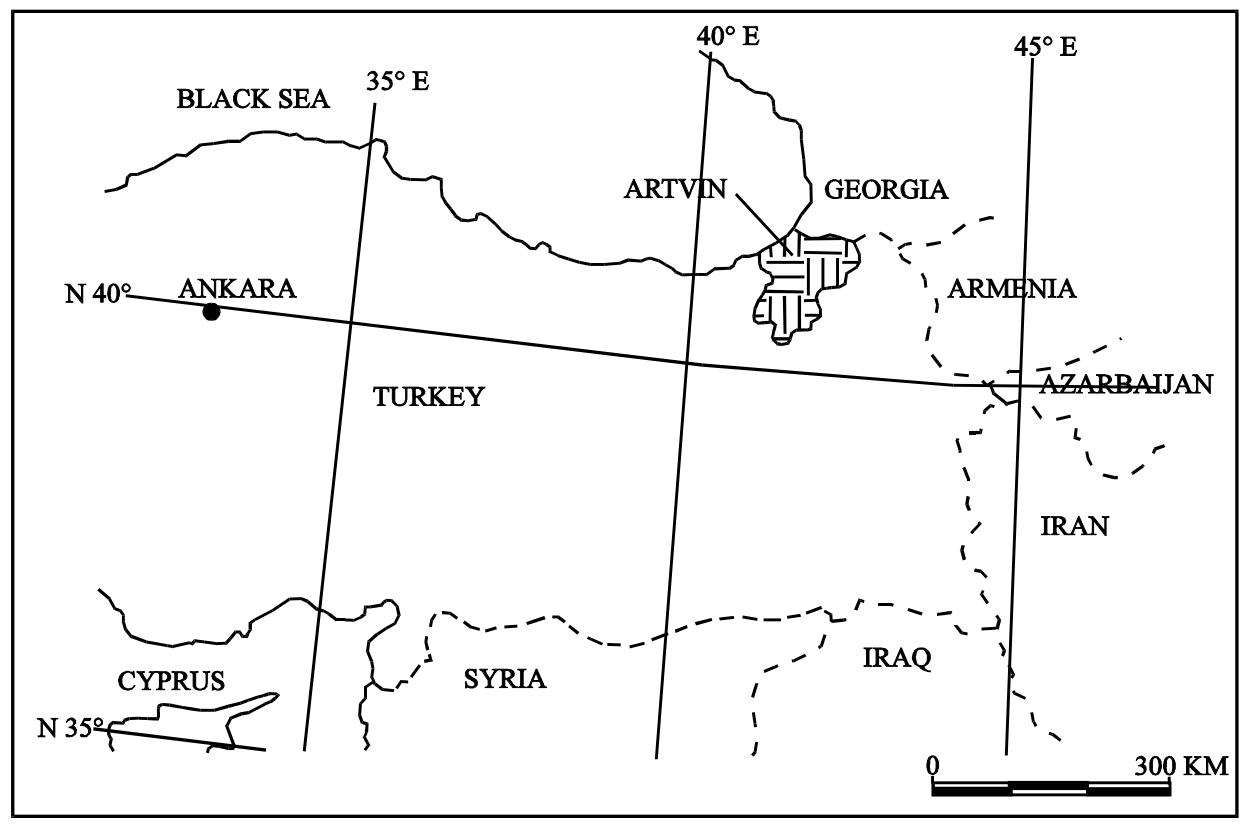

Fig. 1: Study Area (Artvin Province, Turkey)

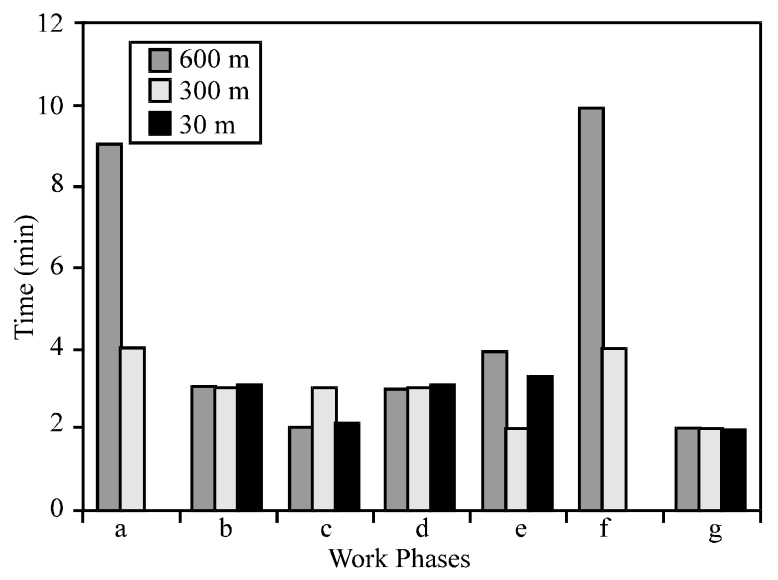

Fig. 2: Job Analysis Total Time

The average times of timber haulage for the tractors installed in two different locations in the district (Table 2 ), while the share of time taken by each stage of operation in the total time is shown in Fig. 2.

As a result of measurements and calculations mode during timber haulage operations, the maximum times were found to be required for bringing the loaded wagon up to the place of unloading and for drawing the loading hook to the loading place to the load. The forestry products hauled were 4-5 $\mathrm{m}$ long Spruce and Fir timbers.

This regreation model used to stepwise method of SPSS 10 statistical programme. Dependent variable is $\mathrm{h}$ (total time) and independent variables are a,b,c,d,e,f,g. R square $\left(\mathrm{R}^{2}\right)$ has been found $0,980(98 \%)$. Regreation model is follow:
$\mathrm{T}=2.812+2.015 \mathrm{x} \mathrm{f}+1.547 \times \mathrm{b}+1.089 \times \mathrm{d}+0.715 \mathrm{x} \mathrm{c}$ $(F=133.543$ and Sig. 0.000)

As it is shown in the Table 3, the transportation time of MB Trac 900 tractor for average $600 \mathrm{~m}$ distance was 33 minutes and for average $300 \mathrm{~m}$ distance was 21 minutes. Amount of load for each time was $3,498 \mathrm{~m}^{3}$ and $3.315 \mathrm{~m}^{3}$. This MB Trac 900 tractor's hour product for $600 \mathrm{~m}$ distance was $6,360 \mathrm{~m}^{3}$, daily product was calculated as $50,880 \mathrm{~m}^{3}$. Also, for $300 \mathrm{~m}$ distance was $9,471 \mathrm{~m}^{3}$ and daily product was $75,768 \mathrm{~m}^{3}$. MB Trac 900 tractor's hour product for average $30 \mathrm{~m}$ pulling was $13,954 \mathrm{~m}^{3}$. Average cost per volume of MB $900 \mathrm{Trac}$ is $9,80 \$ / \mathrm{m}^{3}$ (for average $600 \mathrm{~m}$ skidding), $7,31 \$ / \mathrm{m}^{3}$ (for average $300 \mathrm{~m}$ skidding) and $4,65 \$ / \mathrm{m}^{3}$ (for average 30 $\mathrm{m}$ pulling).

\section{CONCLUSION}

The results of this study have shown that the transport of forestry products by tractors operated in areas located in mountainous terrain, not accessible by forest roads, is a more permanent and efficient haulage method in mountainous forest land when combined with forest roads, since it enables side drawing, eliminates losses in quality and quantity; offers a comparatively short mounting and dismounting time, has an opening-to-production rate of one hundred percent and enables transportation in both directions when required. 
In the light of the results of this study, the following recommendations should be taken into consideration in order to ensure the performance of timber haulage operations in a more effective and productive way.

* For the operation of a tractor in the forest land, there must be an adequate quantity of wood raw materials in the haulage area.

* The tractor operators must definitely be permanently employed workers. This point is important in order to ensure productive working and the careful handling and maintenance of tractors by the operators. For more efficient operation of tractors, a minimum of two workers should be employed at the loading stations. This would enable the tying of hook to the load in a shorter period of time, thereby minimizing any losses of time.

* Persons not specialized in tractors operations should not be employed for this purpose as tractors are expensive pieces of equipment and they cannot always be immediately repaired on site.

* The Forestry Operations Office must pay special care and attention in providing proper accommodation facilities to the works and meeting their food and tools and equipment needs in order to enable them to work in a more secure and productive way in field conditions.

In order to prevent decrease in their efficiency and to reduce fuel consumption, the maintenance of machinery must be performed according to technical specification and in a timely manner. An adequate number of spare parts should be maintained in order to prevent any loss of time in case of urgent maintenance-repair works.

\section{ACKNOWLEDGEMENT}

This work was supported by the Research Fund of the University of Istanbul, Project Number: UDP334/06062004.

\section{REFERENCES}

1. Ozturk, T., 2001. A research on forest tractors using hauling work. Review of the Faculty of Forestry, University of Istanbul, Series B, 51: 101-110, Istanbul, Turkey.

2. Aykut, T., H.H. Acar and N. Sentürk, 1997. An investigation on the comparison of Koller K300, Urus MIII and Gantner skylines used for extraction from compartment in Artvin region. Review of the Faculty of Forestry, University of Istanbul, Series A, 47: 2, Istanbul, Turkey.

3. Acar, H.H., 1997. Investigation on using Geographical Information Systems in the planning of extraction operations with tractors. Productive Functions of Forests. Proceedings of the XI. World Forestry Congress, 3: 215-223.

4. Ozturk, T., 1997. The possibilities of using skyline cranes in Artvin forests in Turkey. Review of the Faculty of Forestry, University of Istanbul, Series A, 47: 2, Istanbul, Turkey.

5. Erdas, O. and H.H. Acar, 1993. Researchs on forest products extraction with MB Trac 900 forest tractor in Artvin region. I. Forestry Council, 3: 127-136.

6. Ozturk, T., 2002. The time analysis and results on MB Trac tractors in Artvin region. Third Balkan Scientific Conference, Proceedings, IV: 241-248, 2-6 Oct. 2001, Sofia, Bulgaria.

7. Seckin, O.B., 1978. Study on extraction by a single farm tractor. Review of the Faculty of Forestry, University of Istanbul, Series B, 28: 1, Istanbul, Turkey.

8. Aykut, T., 1972. Equipment using for time measurement. Review of the Faculty of Forestry, University of Istanbul, Series B, 22: 1, Istanbul, Turkey. 